\title{
Genes, microbiome, diet and inflammatory bowel disease
}

\author{
Robert N Baldassano
}

From 71st Congress of the Italian Society of Pediatrics. Joint National Meeting SIP, SIMGePeD, Study Group on Pediatric Ultrasoun, SUP Study Group on Hypertension

Rome, Italy. 4-6 June 2015

\section{Background}

The incidence of inflammatory bowel diseases (IBD), including Crohn's disease (CD) and ulcerative colitis (UC) is increasing worldwide [1]. These diseases result in chronic, relapsing inflammation of the gastrointestinal tract. The pathogenesis of IBD is currently thought to involve an inappropriate and persistent inflammatory response to commensal gut microbes in genetically susceptible individuals. Advances in DNA sequencing technology have led to the association of $>163$ genetic polymorphisms with risk for IBD. . However, in total, these loci only account for about $13 \%$ of $C D$ and $7 \%$ of UC disease variance. Therefore, it appears that environmental factors make the largest contributions to IBD risk. Among the environmental factors associated with IBD, diet and the intestinal microbiota are the most likely to be modifiable making them targets for prevention and treatment of IBD.

While nutritional therapy has been shown to be efficacious in the treatment of $\mathrm{CD}$, the mechanism of action has not been well characterized. Some hypotheses involve reduction in luminal antigens and food exclusion, a direct anti-inflammatory effect of the formula, improved nutrition, and changes in the gut microbiota [2-5]. The discovery that formula composition does not impact outcome somewhat opposes the hypothesis that enteral nutritional therapy is delivering a substance that is beneficial to the gastrointestinal tract. A recent study completed at our institution showed exclusive enteral nutrition was similar to anti-TNF therapy for induction of remission but partial enteral nutrition was inferior to these therapies. Our data suggest that EEN is likely effective based on exclusion of a "harmful" factor rather

\footnotetext{
Children's Hospital of Philadelphia, University of Pennsylvania, Philadelphia,
} PA 19104, USA

\section{Conclusions}

In summary, it is clear that enteral nutritional therapy is a safe and effective approach to the treatment of Crohn's disease. Induction of remission and healing of the intestinal mucosa can be accomplished with enteral nutritional therapy. Enteral nutritional therapy may also be effective in maintaining remission and preventing post-operative recurrence of disease following resection. An enhanced understanding of the mechanism of action may allow for the development of less restrictive protocols which achieve the same effect. Additionally, mechanistic studies may help respond.

\section{Published: 30 September 2015}

\section{References}

Increasing incidence and prevalence of the inflammatory bowel diseases with time, based on systematic review. Gastroenterology 2012, 142:46-54 e42, quiz e30.

2. Gassull MA: Review article: the role of nutrition in the treatment of inflammatory bowel disease. Aliment Pharmacol Ther 2004, 20(Suppl 4):79-83.

3. Lionetti P, Callegari ML, Ferrari S, Cavicchi MC, Pozzi E, de Martino M, et al: Enteral nutrition and microflora in pediatric Crohn's disease. JPEN J Parenter Enteral Nutr 2005, 29(4 Suppl):S173-5, discussion S175-8, S184-8.

4. van den Bogaerde J, Kamm MA, Knight SC: Immune sensitization to food, yeast and bacteria in Crohn's disease. Aliment Pharmacol Ther 2001, 15:1647-53. 
5. Van Den Bogaerde J, Cahill J, Emmanuel AV, Vaizey CJ, Talbot IC, Knight SC, et al: Gut mucosal response to food antigens in Crohn's disease. Aliment Pharmacol Ther 2002, 16:1903-15.

6. Leach ST, Mitchell HM, Eng WR, Zhang L, Day AS: Sustained modulation of intestinal bacteria by exclusive enteral nutrition used to treat children with Crohn's disease. Aliment Pharmacol Ther 2008, 28:724-33.

doi:10.1186/1824-7288-41-S2-A4

Cite this article as: Baldassano: Genes, microbiome, diet and

inflammatory bowel disease. Italian Journal of Pediatrics 2015 41(Suppl 2): A4.

Submit your next manuscript to BioMed Central and take full advantage of:

- Convenient online submission

- Thorough peer review

- No space constraints or color figure charges

- Immediate publication on acceptance

- Inclusion in PubMed, CAS, Scopus and Google Scholar

- Research which is freely available for redistribution 